Int. J. Speleol., 28 B (1/4) 1999: 55 - 70

\title{
LAND USE AND HUMAN IMPACT IN THE DINARIC KARST
}

\author{
Ivan Gams and Matej Gabrovec
}

\begin{abstract}
The article presents Dinaric karst, human impacts in the area, and its long history of deforestation, transformation into stony semi-desert, and a century long reforestation, where plans to restore the primary thick soil were just hoping against hope.
\end{abstract}

KEY WORDS: Dinaric karst, farming methods, reforestation

\section{Introduction}

The area dealt with in this paper is the Dinaric mountain system between the Soca river and Montenegro. In geology the name Dinaric karst has approximately the same meaning as the Outer Dinarides. Schematically, the age of Mesozoic carbonate rock is decreasing in the Dinaric karst from the north-east towards the south-west. In the north-eastern zone, Triassic dolomite - in some locations only partially permeable prevails, allowing larger rivers to remain on the surface. Here, fluviokarst prevails (Roglic, 1965). Eocene flysch occurs primarily near the coast and on the islands. In the majority of limestone, the share of carbonates is above $92 \%$. Therefore, after the corrosion, not much material remains available for the formation of soil. In the higher central Dinaric karst plateaux prevail, from which steep mountain ridges and isolated mountains rise. Larger plains are found only in the Istria peninsula, in Zadar hinterlands, in Zagora, and in some parts of Herzegovina. The average annual precipitation in the area is around $1500 \mathrm{~mm}$, less on the islands, highest coastal mountains receiving up to $3000 \mathrm{~mm}$ and over.

As the north-western part of Dinaric karst called Kras (the term karst is derived from the name of this region) was a part of the Austro-Hungarian empire, and on the main route from the Danube basin to the Adriatic coast, it was easily accessible and thus attractive to many naturalists. They described it as a stony semi-desert with dolines (Gams 1974, 1991a). This article presents and explains the transformation of forest into semi-desert and, due to the recently abandoned cultivation, the growth of scrub and forest.

\section{A short deforestation review}

The first larger-scale deforestation was brought along by a denser settlement of prehistoric tribes in last centuries BC. Numerous later movements of peoples in this area resulted in additional deforestation such as the migration of the people from the mountains in Montenegro, Herzegovina and Southern Bosnia which began in the $15^{\text {th }}$ century when, before the advancing Ottoman empire, the primary inhabitants fled 
toward West and North. The emigrants who brought their slash-and-burn economy spread the Ortodoxy and the Serbian language $200-300 \mathrm{~km}$ westward from the river Drina (Cvijic, 1922). Seasonal movement of pastoral farmers (transhumance) - along with burning, later also cutting of the forest - was preserved (partially due to the Turkish occupation) locally until this century, when they were observed by first researchers (Cvijic, 1922, 1931). According to the eyewitness Gusic (1957, 1971), the main reason for deforestation was clearing the land for new pastures or meadows and sowing of grain in "novine" (new fields), used only once. Secondary reasons were gathering of firewood for wasteful open fire-places, charcoal-burning, protection from animals, rebels (hajduks) and robbers, hunting, natural and intentionally set fires during the wars. On the islands, which were under the rule of Venice between the $13^{\text {th }}$ and the end of $18^{\text {th }}$ century, and along the coast, one of the reasons for deforestation was also selling of firewood and oak timber for ship construction and pillars for the construction of buildings in Venice.

Protecting role of the forest for soil conservation is essential in Dinaric karst. After the Alpine orogenetic phases the vast horizontal uninterrupted strata are an exception. The tree roots which hold the soil in the fissures lose their function in preventing the denudation after deforestation, and especially burning. Most of the annual precipitation on the coastal mountains fall in form of downpour, $70 \%$ of it in colder winter months.

\section{Types of karst adaptation to agricultural land use.}

The main obstacle for the intensive agricultural use of Dinaric karst is its stony surface. Without removing of stones, the land was suitable for ploughing or spading (i.e. cultivation) mostly only on the alluvium at the bottom of rare river valleys, some uvalas, karst poljes and rare dolines, or on non-karst patches of impermeable rock which decomposes faster. Before the intervention of man, two types of land use predominated in the Dinaric karst: non-karst areas, suitable for cultivation without stone removing, and karst areas, permitting mostly grazing of sheep, goats and cattle. Pastures were turned to meadows only after stones had been removed from the surface. In the low littoral region along the Adriatic coast and especially on the islands, man added the third, garden-orchard-vineyard type of agricultural landscape to arable farming and grazing.

As a consequence of natural and historical conditions, the following types of adaptation to agricultural land-use developed in the Dinaric karst (Gams, 1992):

\subsection{Transforming forests to pastures}

The type with denuded soil and stones protruding from the surface developed after the forest had been cleared for grazing. Morphologically, this is a type of semibarren or barren (stony) karst. After the deforestation, particularly on the slopes exposed to the sun, less compact protruding stones decomposed into rubble forming scree on steep slopes. Smooth surfaces on compact carbonate stone are proof of subsoil origin, generated at contact with humus and clay. After soil erosion the atmo- 


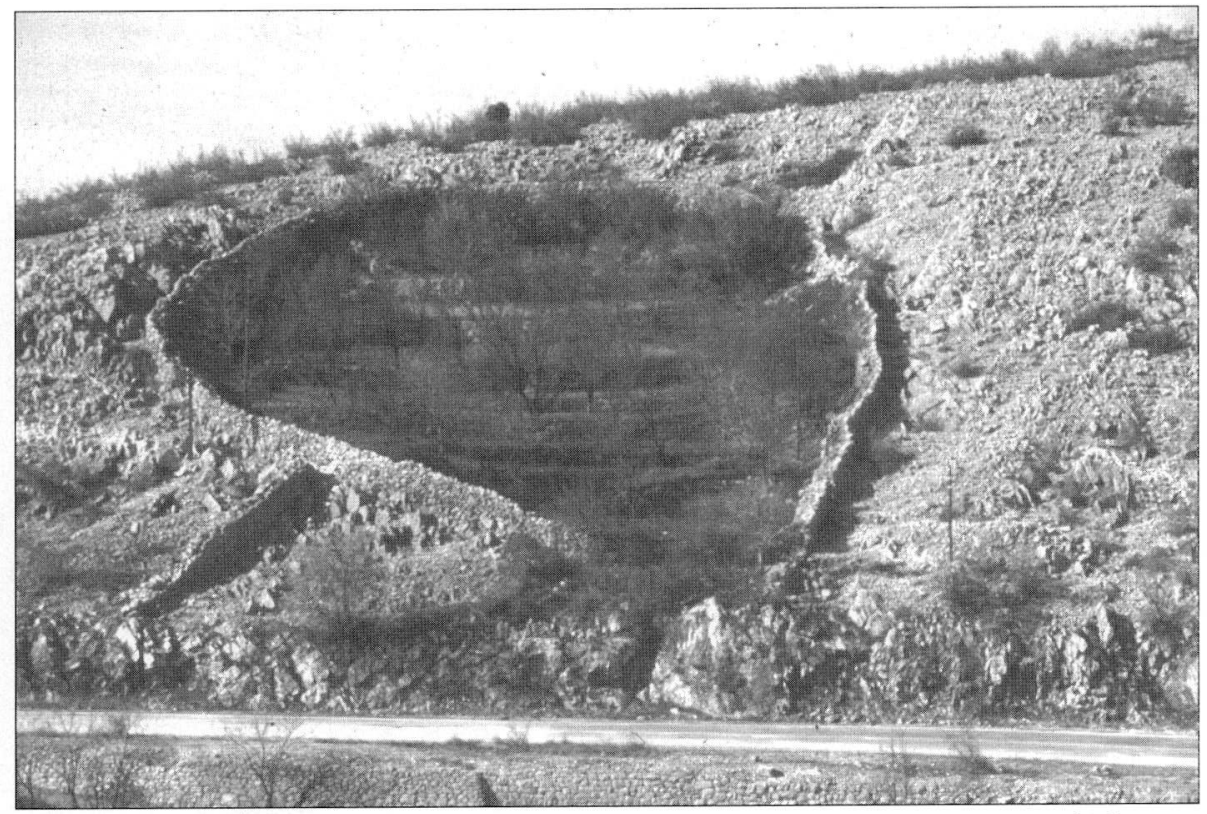

Fig. 1 - A dry wall around the orchard has protected the inner soil from erosion which transformed the surroundings into a stony desert (below Mt. Velebit near Tribunj village, Croatia).

spheric processes, above all, mechanical weathering and corrosion by meteoric water, generate rough surfaces of these stones. From the vertical distance between the lines which denote the smooth surface and the rough one, the reduction of soil can be estimated (Gams, 1973). On steep coastal mountains and high plateaux in their immediate hinterlands, where - particularly in the south-eastern part of the Dinaric karst - the summer is the driest period of the year, the karst was the most stony and barren in the old Montenegro, in low Herzegovina and in the coastal mountains in Dalmatia. In the Modern Age, these were the first places where agricultural population lost its source of existence due to eroded soil. A typical example is the old Montenegro (Crna Gora). The name derives from the Montenegrine word "crnogorica", meaning dark submediterranean coniferous forest which initially covered the area and was removed in the Modern Age. After the slash-and-burn system was abandoned, forests recovered faster and more successfully in the inland Dinaric area with continental climate than in the coastal area.

\subsection{Transforming pastures into meadows}

The second type was established by the introduction of meadows. Farmers cleared the stones protruding above the surface to transform pastures into meadows, where they could cut the grass. The removed stones were buried under the soil, accumulated in heaps or in lines (groblje, also gomile) or used for building dry (karst) walls at the edges of meadows, dolines or plots of land. The oldest dry walls 


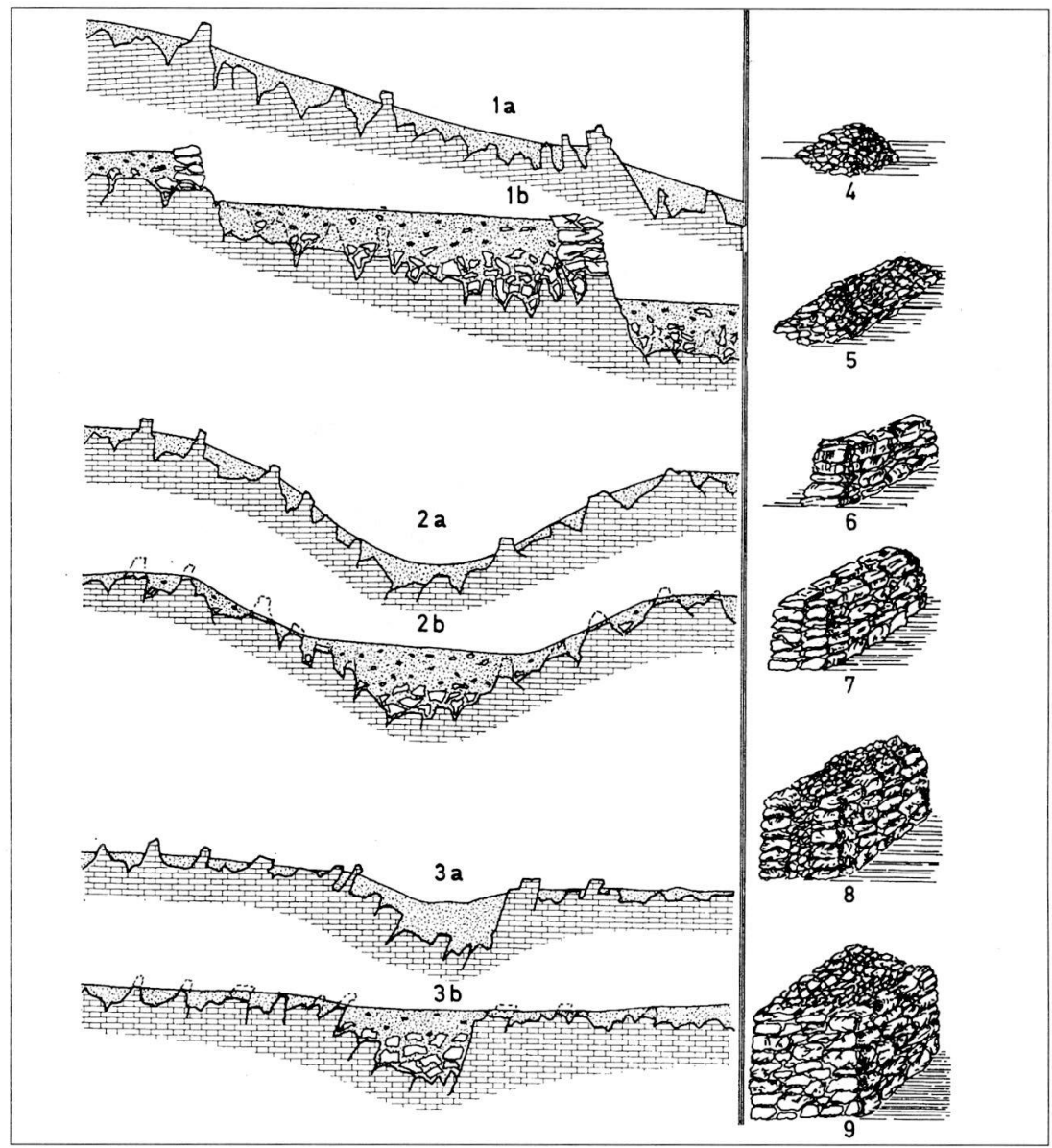

Fig. 2 - Some forms of the transformation of the karst surface due to cultivation. a) - natural surface, b) - transformed and cultivated surface.

1 - Field terraces on slope in semicovered karst. 2 - Transformation of the funnel-shaped doline into a more bowl-like doline. 3 - Transformation of the semicovered karst into the covered karst in a meadow.

Forms of accumulated rubble collected at the process of cultivation: 4 - a heap of stones , 5 heaps of stones arranged in a row, 6 - a single-row wall, 7 - a double-row wall, 8 - a doublerow wall with inner filling, 9 - "kamenar" - rectangular tower (Acc. to Gams, 1974).

are recorded from the Roman period.

\subsection{Making ploughing possible}

The third type came into existence together with adapting karst surface to arable land. This type developed with removing of stones from the surface and from the soil which was spaded at first and ploughed later. Therefore, accumulations of rubble are 
larger in this type. The depth to which they had to clear the stones had been increasing in accordance with modernisation of ploughs - tractor ploughing requires a depth of over $28 \mathrm{~cm}$. Along with types 1 and 2, type 3 is more common in more densely populated littoral lowlands with submediterranean climate. The karst surface remained more stony and with fewer walls where refugees from the Ottoman Empire settled and continued with grazing (Ravni kotari, Bukovica, part of Herzegovina). For different reasons, substantial part of the low Herzegovina and the old Montenegro out of the coastal area, as well as Rumija, also belong to this type. Removed stones are also found by cave explorers at bottoms of potholes, they are uncovered in road cuttings, in the course of digging ditches for various pipelines or cables, they are used for construction of buildings and levelling of field roads and cart tracks. On the western edge of the Kras region, it was crushed by cannon antiinfantry mines during the World War I (1915-1917) at the site of the stationary Austrian - Italian front, or it was built into military buildings in the hinterland of the front (Man's Impact..., 1987). From such removed stones the so called enclosing walls were built, i.e. dry walls on the border between pastures and arable land, around the dolines and on both sides of village roads, preventing livestock from grazing on meadows and fields.

\subsection{Artificial terraces with scarps}

At the lower end of artificial terraces supporting walls were built from removed stones. The shelves were levelled with accumulated remaining stones behind the supporting walls and covered with the soil which was transported from the vicinity. If the walls surround all four sides of the parcels, a "box-like landscape" is formed, in which dry walls rise above the scarps, usually up to the chest height (building to such a height did not require additional help).

\subsection{Adaptation of dolines for cultivation}

Stones, removed from the doline slopes, were thrown into a hole, dug into the ground at the bottom of the doline. Then the bottom of the doline was covered with the soil from doline slopes or from the closer surroundings; in this way, a larger level area suitable for ploughing was acquired. Places of removed soil, characterised by high stones with smooth surface, can be detected only by an expert geomorphologist.

\subsection{Trench-ploughed vineyards}

This type differs from the fourth type (3.4.) in deeper removing of stones. Therefore, scarps and dry walls are more numerous.

\subsection{Narrow stair-like vineyards}

They are typical on the Adriatic islands and coastal areas on the continent, exposed to the sun and sheltered from the bora. Larger uninterrupted areas are on the islands around the villages, and on the mainland coast mainly around larger cities 


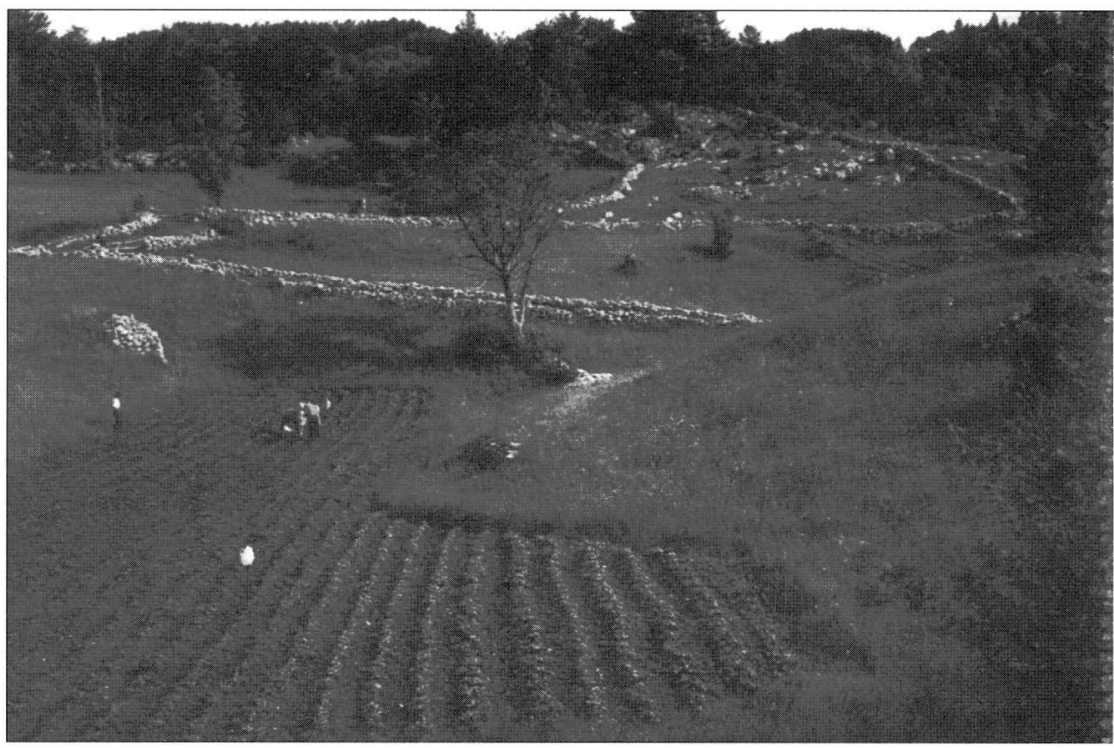

Fig. 3 - The first phase of karst cultivation is visible in a newly settled area: arable land in irregular patches with thicker soil between the more stony surface is cultivated with spade. The high stones with smooth surface on the slope behind prove the removing of soil for the accumulation on the near acre now abandoned for meadows (the Banjscice plateau, $800 \mathrm{~m}$ of altitude, 1970, Slovenia).

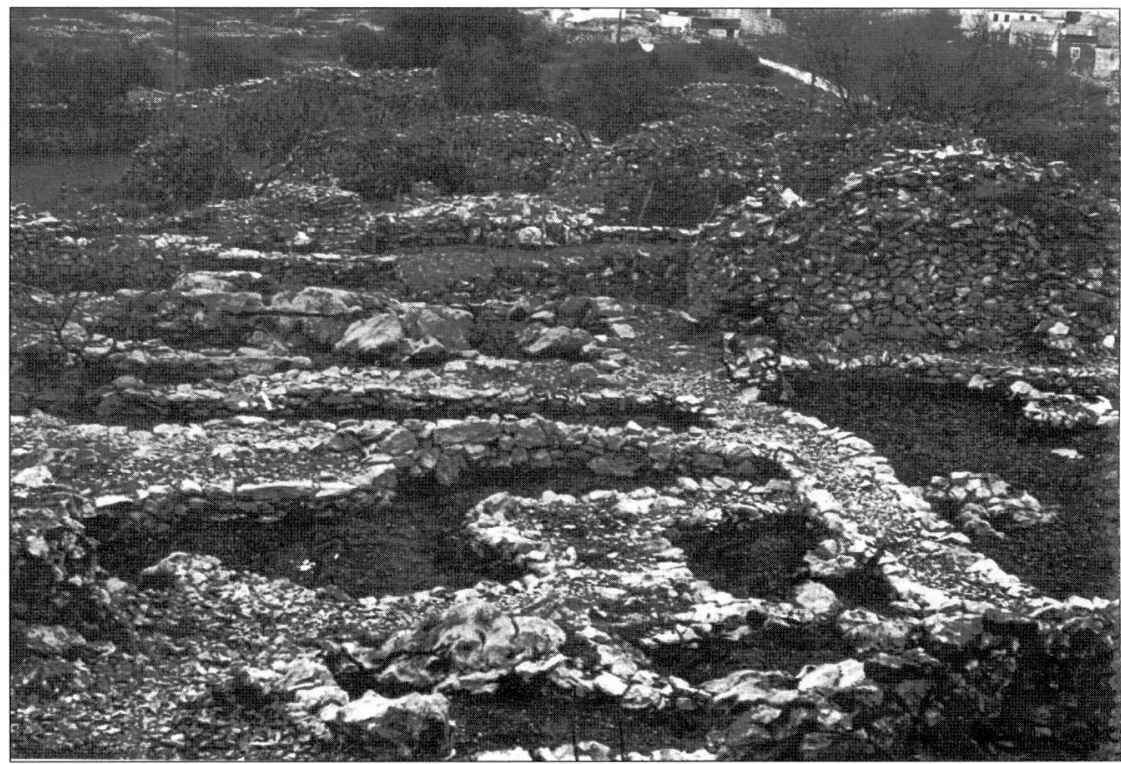

Fig. 4 - A new vineyard in Vrboska where the dry walls take up more surface than soil (the Hvar island in 1992). 


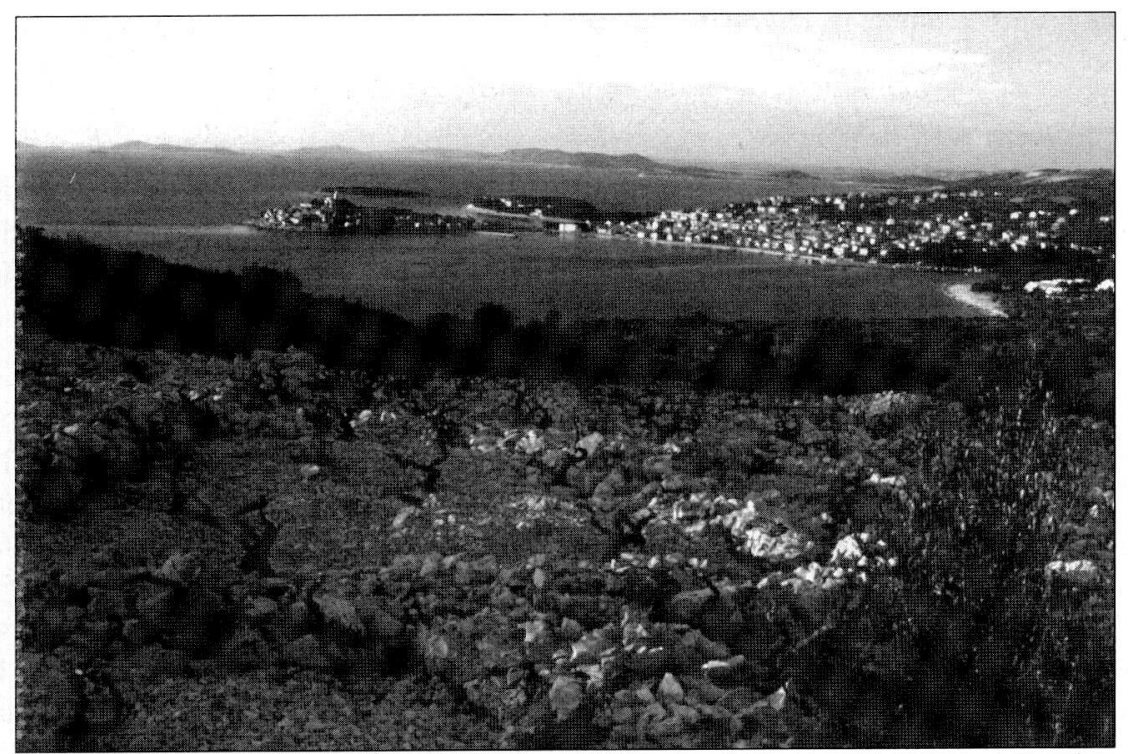

Fig. 5 - A new vineyard torn from the stony desert at Primosten, Dalmatia. To protect the soil from the bora also the soil around the vines is covered by rubble.

(Rabac, Zadar, Sibenik, Split - on the northern slope of Marjan mountain, above the cities of Boka Kotorska and Dubrovnik, etc.)

This type spread mostly in the last two centuries on the stony steep slopes when better land was no more available. It largely expanded in the second half of the previous and in the first half of this century when the price of wine increased abruptly after the occurrence of Peronospora, Phyloxera and Oidium in France in the middle of the previous century, while in coastal Dalmatia it appeared several decades - on the islands even half a century - later. Since better agricultural land had already been cultivated, new vineyards were made on higher and stonier slopes. After the Second World War, the Dalmatian municipality of Primosten distributed stony common lands among the villagers so that they could convert them into vineyards. Surfaces covered with accumulated removed rubble are there larger than surfaces covered with soil. The image of these stony vineyards, symbol of the struggle for survival in a harsh environment, decorates a wall in one of United Nations buildings in Geneve. Where an access with carts to inner parcels is impossible due to piled stones, abandoning of land cultivation has been general in recent times.

On the islands, the amount of removed stones during the introduction of more intensive crops was much larger comparing to continental areas due to Mediterranean crops and especially due to immigration of refugees from the Ottoman part of the continental Dinaric karst (Carter, 1992), who settled the remaining land of a marginal quality. In Istria and on Slovenian karst, types 6 and 7 are generally not so common.

Removed stones were piled in several meters wide mounds, following the slopes, 
usually at the contact of land belonging to different owners (on the Krk island, especially around Punat, named barbakan or varvakan).

\subsection{Adaptation for orchards}

The last type of adapting occurred with plantations of fruit trees. Among them, olive trees, and to a lesser degree fig trees have always been prevailing in the Mediterranean climate. Soil funnels are smaller than crowns of trees so that the soil between individual trees need not be cleared so deeply.

\section{Karst dry walls as an indicator of the adaptation of karst for cultivation.}

The stones removed from soil have mostly been accumulated in dry walls. The thickness of walls depends on the construction type (single-row, double-row or double-row with smaller rubble in the middle) and on the volume of removed stones and their thickness. Special and rarer forms are stony rectangular or rounded "kamenari", several meters wide and up to 50 meters long, 1.3 - $2.5 \mathrm{~m}$ high heaps of stones. Some were formed by joining of smaller walls or stone heaps, gaining more arable land. In the vicinity of settlements, thick walls were built along the roads on which merchandise was carried (Gams, 1974).

The amount of accumulated stones on the surface increases in accordance with the intensity of land use or higher range of adaptation type. From the volume of stones and from specific weight (2.7), the weight of built-in stones was calculated for selected locations and divided by the surface of cultivated land from which the stones originate. The average amount on Slovene Kras region ranges between 50-200 $\mathrm{kg} / \mathrm{m}^{2}$. On the $1830 \mathrm{~m}$ long profile across the Velo Polje karst plain on the Hvar island, where fields prevail over the orchards, it was $236 \mathrm{~kg} / \mathrm{m}^{2}$. On the measured orchard (especially olive tree) parcels on the Krk (Punat), Vis, Bisevo and Hvar (Starigrad) islands, it sometimes amounts to $1000 \mathrm{~kg} / \mathrm{m}^{2}$, in vineyards up to 1400 $\mathrm{kg} / \mathrm{m}^{2}$. An extreme weight of removed stones in the seventh type of karst adaptation was measured on the Hvar island above the village of Dol, where it amounted to 2070 $\mathrm{kg} / \mathrm{m}^{2}$. On the measured olive tree parcel above the town of Punat, the soil was thinned by $11-30 \mathrm{~cm}$ only because of stone removal. The weight of scrapes which remained in the soil after the removing of larger stones and which amount to several \% of the total weight of the soil, is not included in these calculations. They also contribute to higher temperature of the soil. Locations with above-the-average number of walls were chosen for measurements (Gams, 1992, Man's Impact..., 1987).

On the littoral Dinaric karst, special kinds of buildings were built from the removed stones. In the corner of the parcel two walls were added to two corner walls and the rectangular room was covered with branches to make a shelter for the protection of shepherds and other people against the rain and the wind. From stratified limestone, rectangular buildings with domed roof were built, used as shelters by farmers from remoter villages (so called field). Especially on the Hvar island, several 2 - 3.5 m high buildings, named "trim", remained (Fig. 6). Outer walls, built from stratified limestone, are closing up towards the centre as they become higher, so that on the 
outer side, a stone path can lead upwards for carrying stones, needed for the construction of the top of the $3-4 \mathrm{~m}$ high dome. With its name alone, the trim reminds us of a building without inside rough coating, named trullo in the Italian Puglia region, nowadays used mainly as a storage, while more comfortable variants are used for living.

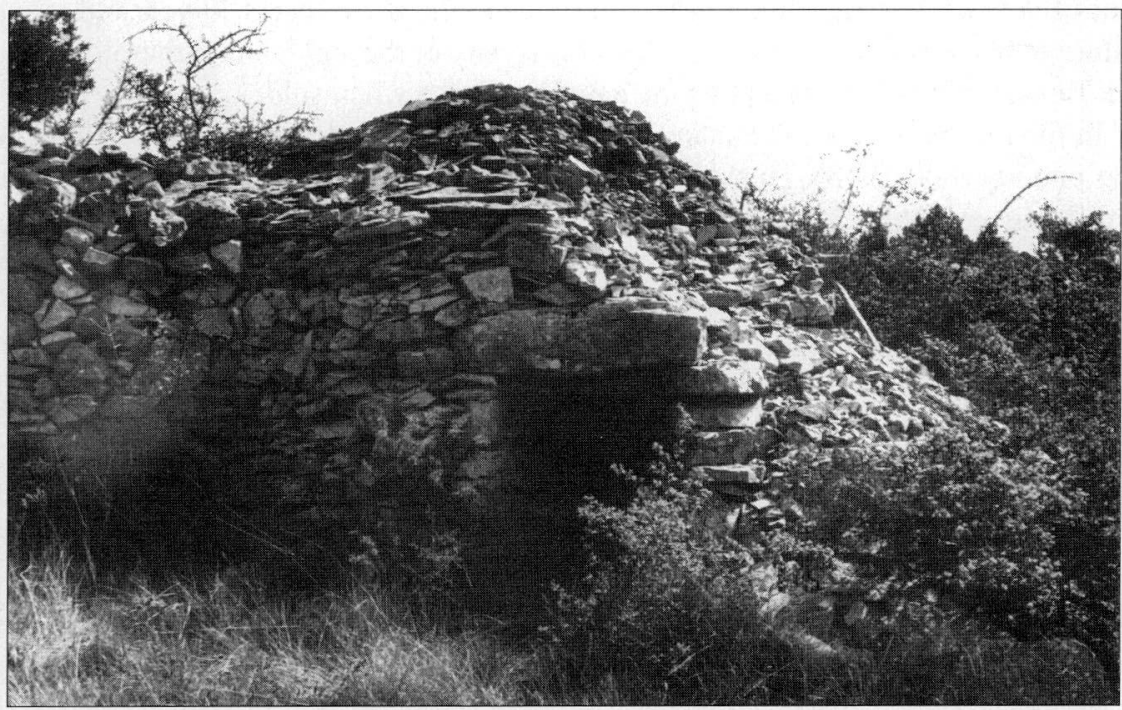

Fig. 6 - A stony shelter built of cut-off stones for man or cattle in the field (the Losinj island near Veli Losinj).

\section{Modern reforestation}

In the continental part of the Dinaric karst, vast forests existed throughout the history in some mountainous areas. On the islands and in some places along the coast, man turned the majority of the forest into evergreen scrub associations of maquis type with jasmine, ash, hop hornbeam, Quercus pubescens, myrtle, etc. Larger cities (Dubrovnik, Split, Zadar, Trieste) have been issuing orders and regulations since $12^{\text {th }}$ century, limiting deforestation to protect drinking water, to provide protection against the bora, for hunting and other reasons, or they even enacted reforestation decrees (Gusic, 1957, 1971). The pollen analysis of the stream delta at the coast in the town of Starigrad on the Hvar island, where a Greek, and later a Roman settlement was located, showed sedimentation of the alluvium from the nearby slope in the time of forest clearing to acquire the land for cultivation. After the forests returned, the stream dried-out (Gams, 1992, p.68). The first larger and planned reforestation took place at the beginning of 19th century during the short existence of French Illyrian Provinces. The second scheme, implemented on a larger scale and more successfully, took place in the second half of the $19^{\text {th }}$ and at the beginning of the $20^{\text {th }}$ century under the AustroHungarian Empire, when non-agrarian jobs reduced agrarian pressure on land in the north-western Dinaric littoral karst. This reforestation in the region Kras was of great 
importance. In the years 1870 - 1911 the government planted 26,000,000 plants only in a part of Kras. After many trees of the world had been tested, the black pine (Austrian pine, Pinus nigra Arn.), imported from other parts of the state, was planted there and 56,000 local people collaborated. Foresters from all Europe came to observe the experiment which proved successful. But the new $2-4 \mathrm{~cm}$ thick soil cover built of not yet fully decomposed pine needles in the more than 100-year old monoculture of black pine forest is acid. The biodiversity of the soil fauna is therefore reduced. Besides the timber of black pine has a low price when sold.

In the region of Kras, the share of the forest increased from 10 to $50 \%$ in a 200year period (1800-1998). This data is approximate because the Kras region belonged to different statistical and administrative units and because definitions of land use categories have been changing over time and space. However, within a few decades, it can become a type of forested karst. A similar expansion of the forest area is also characteristic for Slovenian Dinaric karst in the continental climate zone. The Kocevje district was most severely affected during the World War II (1941-1945). In

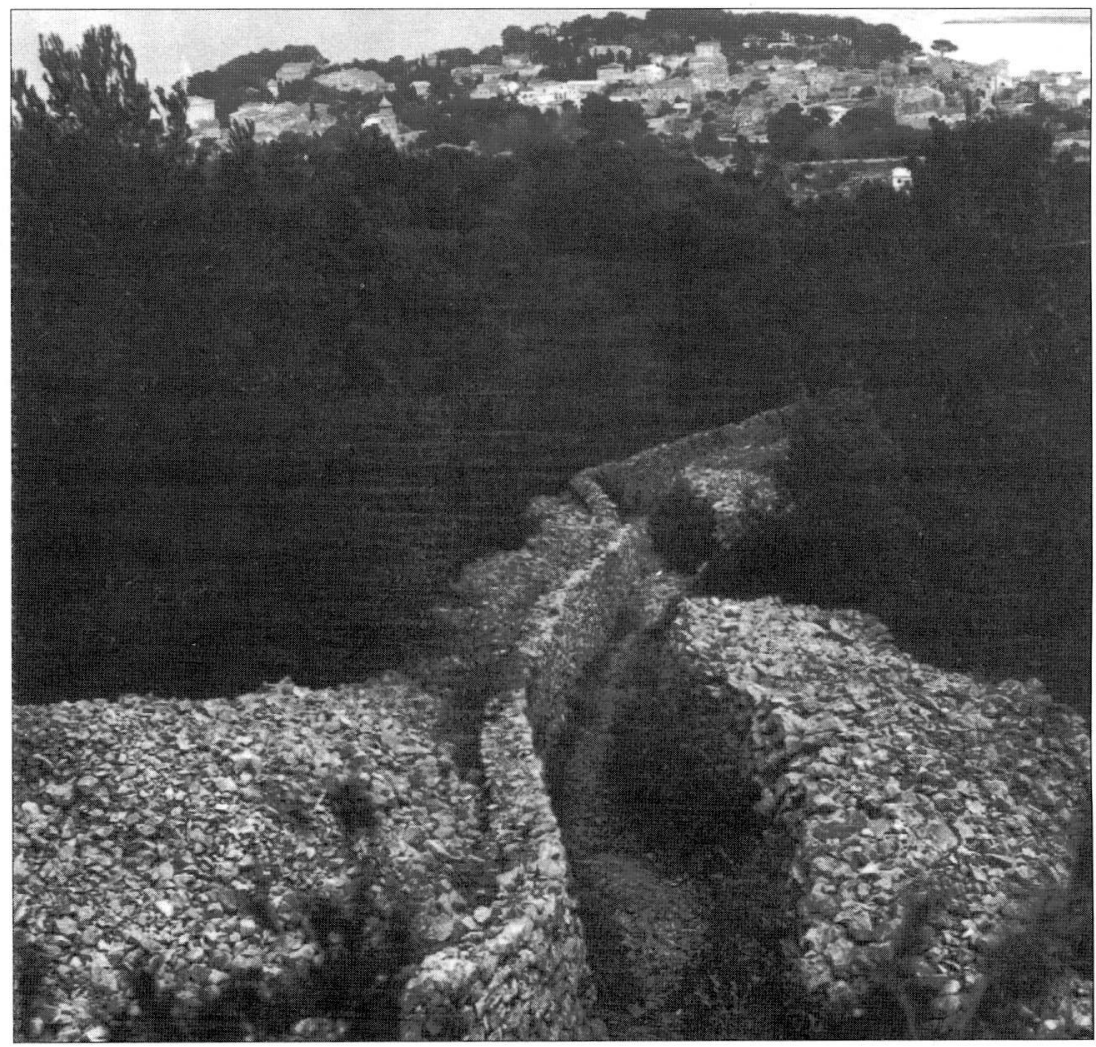

Fig. 7 - A cart track above Veli Losinj village with abundant dry walls on both sides (called ulica $=$ street $)$. 
1870 , the forest share was $34.4 \%$, while at present it amounts to $90 \%$ of the same area. Towards the south-east of Dinaric karst, however, this transition occurred much later.

\section{Changes of land use in the Dinaric karst after 1960 in the light of the official statistics}

The area of the Dinaric karst, shown on the map, is today divided among four states, i.e. Slovenia, Croatia, Bosnia and Herzegovina, and Yugoslavia (Montenegro). In order to acquire maximally comparable data, the period when the whole area belonged to one state, i.e. former Yugoslavia, was chosen for the analysis of land use change, and a single source - Statistical Yearbook of Yugoslavia (Statisticki godisnjak FNRJ 1962, Statisticki godisnjak SFRJ 1963, Statisticki godisnjak SFRJ 1990) - was used. Two kinds of data on agricultural areas exist. For the former social sector, data was acquired on the basis of reports of agricultural companies and cooperatives, while for the private sector, estimates were made according to data compiled by statistical authorities. They relied mostly on recent cadastral data, but they also gathered information from other sources. Data for forest areas was acquired with the use of forest fund inventories made in 1961 and 1979. Unfortunately, agriculture and forestry sources are not always harmonised. In some cases, the same areas (usually overgrown pastures) are recorded as forests by the forestry sector, and as pastures by the agriculture sector. In these cases, the sum of total area exceeds $100 \%$, or obvious errors occur. These errors were eliminated by assuming data of the previous or the following year. Basic territorial units - municipalities were joint into 12 units, homogenous to a largest possible degree in a natural geographic sense. The earliest available data is for the year 1961, the latest available data is for the year 1989, while for the forests, unfortunately, the latest available data is for the year 1979 .

Due to general agriculture intensification, the share of fields in this period was reduced in the whole area, in Croatia especially vineyards and olive-tree plantations. The spread of forests, which is the consequence of the overgrowing of pastures, is a general phenomenon. Meadows and pastures combined are declining in spite of the fact that the area of meadows expands on the account of abandoned fields. There are of course considerable differences among regions. In littoral Slovenia, in flysch hills, agriculture intensification and expansion of vineyards is taking place. In the continental Slovene Dinaric karst (the Notranjsko region) the share of a high forest is increasing rapidly on the prevailing high karst plateaux. In the lower Dolenjsko region, densely inhabited since prehistoric times, grassing over prevails in recent decades (Gabrovec, Kladnik, 1997).

On the Slovene Dinaric karst, differences between the land use on limestone and dolomite areas have been more thoroughly studied. The most evident differences occur in the share of meadows - on dolomites, their share exceeds the share of pastures by $10 \%$ (dolomite $27 \%$, limestone $17 \%$ ). On limestone, there are fewer meadows due to more stony surface preventing grass cutting, which results in a larger share of 
pastures. On dolomite, meadows were very frequently set on very steep slopes, where the use of mowing machines was impossible. These steep meadows were consequently frequently left to overgrowing and are already entirely overgrown by the forest in some places. Therefore, the forest area expanded much faster on dolomite than on limestone. On the Dinaric karst of continental Slovenia, the forest area on dolomite increased by $17 \%$ in the period 1953-1987, while on limestone it increased only by $7 \%$. On limestone and dolomite, pastures are being heavily overgrown by forests - their area was reduced by $36 \%$ on limestone and by $29 \%$ on dolomite. In the test areas, a detailed land use analysis was elaborated on the basis of the first, so called Emperor Francis' Cadastre from mid-twenties of the 19th century. At that time, there were fields in virtually all bottoms of small dry valleys with thicker soil on dolomite. These were preserved up to the present only on $10 \%$ of former area, while

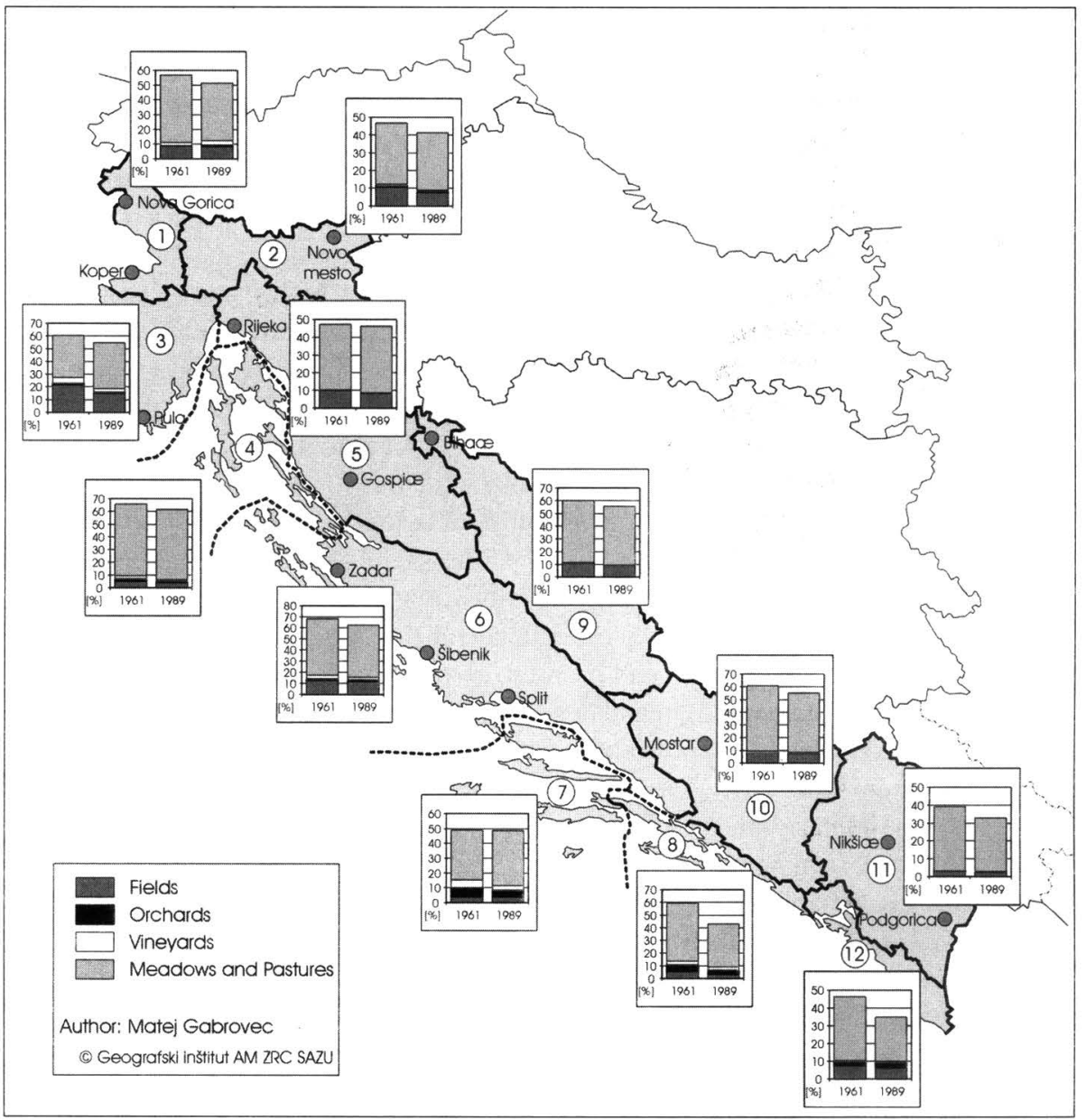

Fig. 8 - Land use in the Dinaric Karst 1961 - 1989. 
the rest is, like meadows, being overgrown by forest (Gabrovec, 1995).

In Croatia, the greatest reduction of agricultural land occurred on the Adriatic islands where the area of vineyards decreased by more than a half in the last thirty years. Here, the abandoning of agriculture is related to high emigration levels (Cede, Steinicke, 1997; Crkvencic, 1992). Croatian statistics also publishes data on fallow and uncultivated arable land. In 1996, their share in Croatia amounted to $28 \%$, while on the Dinaric karst it was approximately twice as large. In coastal Zadar and Sibenik-Knin districts, the share of uncultivated arable land even exceeded $70 \%$ (Statisticki ljetopis 1997), which is obviously also the consequence of the war in the 1991-1994 period and the emigration of Serbian population. Before disintegration of the communist Yugoslavia, only slightly over $10 \%$ of arable land in Croatia was uncultivated, $22 \%$ in Dalmatia, while in the nationally mixed Lika region it amounted to $39 \%$ already at that time (Statisticki godisnjak SR Hrvatske, 1998).

Unlike in Croatia, the share of (though small) vineyard and orchard areas in Bosnia and Herzegovina and Montenegro increased. In Herzegovina, large state-

\begin{tabular}{|c|c|c|c|c|c|c|c|c|c|c|}
\hline \multirow[t]{2}{*}{ Region } & \multicolumn{2}{|c|}{$\begin{array}{l}\text { cultivated } \\
\text { fields }\end{array}$} & \multicolumn{2}{|c|}{ orchards } & \multicolumn{2}{|c|}{ vineyards } & \multicolumn{2}{|c|}{$\begin{array}{l}\text { meadows } \\
\text { and } \\
\text { pastures }\end{array}$} & \multicolumn{2}{|c|}{ forest } \\
\hline & 1961 & 1989 & 1961 & 1989 & 1961 & 1989 & 1961 & 1989 & 1961 & 1989 \\
\hline \multicolumn{11}{|l|}{ Slovenia } \\
\hline Littoral & 8.9 & 8.4 & 0.2 & 1.1 & 2.0 & 2.9 & 45.7 & 38.9 & 33.1 & 40.7 \\
\hline Notranjsko and Dolenjsko & 10.5 & 7.5 & 0.9 & 0.9 & 0.7 & 0.7 & 34.7 & 32.3 & 50.0 & 61.8 \\
\hline \multicolumn{11}{|l|}{ Croatia } \\
\hline Istria & 21.5 & 15.1 & 1.5 & 0.9 & 4.4 & 2.5 & 33.0 & 36.2 & 28.1 & 38.0 \\
\hline Kvarner islands & 4.8 & 4.2 & 2.4 & 1.3 & 2.4 & 1.0 & 56.1 & 55.1 & 22.9 & 30.4 \\
\hline Gorski Kotar and Istria & 10.0 & 8.5 & 0.2 & 0.2 & 0.0 & 0.0 & 37.2 & 37.5 & 49.6 & 52.1 \\
\hline $\begin{array}{l}\text { Northern and Central } \\
\text { Dalmatia }\end{array}$ & 12.4 & 11.8 & 1.8 & 1.6 & 3.0 & 2.3 & 51.0 & 47.1 & 33.6 & $\overline{36.4}$ \\
\hline Central Dalmatian islands & 3.8 & 4.0 & 6.3 & 4.6 & 5.3 & 2.7 & 33.4 & 37.2 & 51.5 & 47.7 \\
\hline Southern Dalmatia & 5.8 & 3.3 & 5.3 & 3.7 & 2.5 & 2.3 & 45.8 & 33.8 & 37.1 & 54.9 \\
\hline \multicolumn{11}{|l|}{ Bosnia and Herzegovina } \\
\hline SW Bosnia & 11.2 & 9.4 & 0.1 & 0.2 & - & - & 48.7 & 46.0 & 38.9 & 40.3 \\
\hline Herzegovina & 9.1 & 7.5 & 0.1 & 0.3 & 0.5 & 0.7 & 51.1 & 46.6 & 32.6 & 46.9 \\
\hline \multicolumn{11}{|l|}{ Montenegro } \\
\hline Littoral Montenegro & 7.6 & 6.2 & 2.5 & 3.4 & 0.3 & 0.4 & 35.7 & 24.8 & 30.4 & 42.0 \\
\hline Central Montenegro & 3.0 & 2.2 & 0.2 & 0.3 & 0.1 & 0.4 & 35.8 & 29.9 & 38.4 & 38.1 \\
\hline
\end{tabular}

Table 1 - Land use on the Dinaric karst in the mediterranean and submediterranean climate in the period 1961-1989, in \%.

owned agricultural companies with large fruit plantations and vineyards in the Neretva valley contributed to the increase. In Herzegovina, pastures absolutely prevail among the land use categories - together with meadows, they amount to approximately $50 \%$ of total area. In 1961, there were only $10 \%$ of meadows in this area. In Montenegro, large hydromeliorations were carried out in the vicinity of Podgorica, Danilovgrad and Ulcinj, where fruit trees and vineyards were planted. Otherwise, livestock breeding remains the principal agricultural activity in Montenegro 
(Enciklopedija Jugoslavije, 1987).

The process of overgrowing of pastures and marginal meadows and spreading of forests due to deagrarization initially appeared at the end of the previous century in the north-western part of the Dinaric karst, while the remaining karst area met changes mainly after 1945 in the new communist state of Yugoslavia which forced industrialisation and deagrarization and banned goat-breeding in 1948 and 1949. Especially on the islands, the abandoning of intensive crops was accelerated by rapid depopulation after 1945. Along with the increase of areas overgrown with bushes and young trees, and along with the increasing number of summer tourists, forest fires are becoming more common every year. According to a source from 1970 (Androvic, 1970), 2407 hectares of forest were burnt every year. However, in the devastating year 1998, the burned-over area was considerably larger.

After 1956, a considerable portion of pastures on the Dinaric karst, especially on steep slopes, was overgrown with scrub and - in the hinterland of the coast - a young deciduous forest. On the islands, the scrub vegetation (maquis) is already gradually transforming into a low forest. Because during the war period (1991-1994) in the continental part of the Dinaric karst many settlements, especially those with mixed national and religious composition of the population, were abandoned, and because some refugees never returned, a lot of agricultural land was abandoned (Lika, Ravni kotari, SE Herzegovina). All these changes haven't been recorded in the cadastre yet, while other published data is not reliable if sources are not quoted. The same holds for the study by Androvic (1970) who for the Dinaric karst area in Yugoslavia (covering $56,618 \mathrm{~km}^{2}$ ) quoted $38 \%$ of non-forest area, $6.4 \%$ of degraded forests, $14.1 \%$ of thicket and macquis, while total agricultural land amounted to $18 \%$. In the Mediterranean and submediterranean area, $12.2 \%$ of the area was infertile.

Considering this data, we must bear in mind that forest was a natural vegetation before the arrival of man, even in the coastal Dinaric karst. This was already proven to doubters in the time before planned reforestation in the previous century in the Kras region by successful plantations of black pine which today spreads with its own seed.

\section{Conclusion}

Most of the Dinaric karst within the influence of Mediterranean climate belongs to the so-called semi-barren karst. This is a type of karst with outcropping rocks which do not only reach to the level of turf but outcrop for several centimetres, or even decimetres, from the ground. Such forest and stony karst had to be adapted for land use by clearing off forest and stones from the surface and out of soil respectively. The degree of adaptation depended, above all, on the purpose of agrarian use of the land; but as concerns the appearance, it reflects in the forms and modes of depositing the removed stones which are typical of the karst cultural landscape. The amount of the removed stones from soil is up to $2000 \mathrm{~kg} / \mathrm{m}^{2}$ in vineyards.

The deforestation and adaptation of karst land for agricultural use in the Adriatic islands and in the coastal area was similar as elsewhere in the Mediterranean. In the 
mountainous Dinaric hinterland the process of massive migration of tribes since $15^{\text {th }}$ century renewed the deforestation and slash-and-burn cultivation which brought the heavy soil erosion and stony character of the surface. The research in northern Vancouver Island in British Columbia has recently proved the fatal effect of primary deforestation upon limestone slopes for soil erosion (Harding, Ford, 1993). The same causes for deforestation are still active in the karst countries of Southeastern Asia. There, the soil erosion is still rapid, e. g. in the $69,742 \mathrm{~km}^{2}$ large studied mountain karst region in Guangxi in South China the annual mean soil erosion is $265 \mathrm{t} / \mathrm{km}^{2}$, as an effect of augmentation of population and spreading of cultivated area (Xiaoping, 1998). For them, the results of our research on the rapid soil erosion after deforestation of karst and the long-term, yet partial recovering of to the natural vegetation in the Dinaric Karst, may be of interest. A planned forestation began in the north western part of the littoral karst in the second half of the $19^{\text {th }}$ century and in the rest of the Dinaric karst after the Second World War, when the rapid transformation of the social structure to the nonagrarian jobs, depopulation and the ban of the goat breeding began. Where the maintenance of dry walls was abandoned in the time of deagrarization, they are either decaying or were removed in some places due to machine ploughing or widening and levelling of roads; sometimes stones are also crumbled and used for the maintenance of roads. The highest decrease has been recorded in the areas with olive tree plantations and vineyards on steep slopes, where dilapidated scarps and walls turned some terraced slopes into scree (i.e. around Bakar), on which scarce scrub grows.

Although the quoted data is only approximate, the nations in developing tropical areas where population grows rapidly, can take it as a warning. The land degradation on karst can be caused by unplanned slash-and-burn cultivation or clearcutting of forests for timber or their conversion to pastures.

\section{REFERENCES}

ANDROVIC M., 1970. Zascita suma na krsu. Simpozij o zasciti prirode u nasem krsu. Zagreb.

CARTER E.W., 1992. Agriculture on Hvar During the Venetian Occupation: a Study in Historical Geography. Geografski glasnik, 54: 45-62.

CEDE P., STEINICKE E., 1997. Prozesse und Strukturen der Entvölkerung auf den Kvarner und Dalmatinischen Inseln. Mitteilungen der Österreichischen Geographischen Gesellschaft 39: 231-260.

CRKVENCIC I., 1992. Some Indicators of Social-Geographic Changes on the Island of Cres during last twenty years. Acta Geographica Croatica 27: 35-47.

CVIJIC J., 1922. Balkansko poluostrvo i juznoslovenske zemlje. I., Beograd.

CVIJIC J., 1931. Balkansko poluostrvo i juznoslovenske zemlje. II. Beograd.

Enciklopedija Jugoslavije, 1983 - 1989. Zagreb, 1 - 4.

GABROVEC M., 1995. Dolomite Areas with Particular Consideration of Relief and Land Use. Geografski zbornik, 35: 7-44.

GABROVEC M., KLADNIK D., 1997. Some New Aspects of Land Use in Slovenia. Geografski zbornik, 37: 7-64. 
GAMS I., 1971. Podtalne karske oblike (Subsoil Karst Forms). Geografski vestnik 43: 2745.

GAMS I., 1973. A new method of determining karstic soil erosion. Symposium on Karst morphogenesis. Proc. 6th Int. Congress of Speleology, II, Olomouc. Praha 1976.

GAMS I., 1974. Kras (Karst). Slovenska matica. Ljubljana.

GAMS I., 1990. Depth of Rillenkarren as a measure of deforestation age. Proc. Int. Conference on antropogenic impact and environmental changes in karst. Studia Carsologica, 2 (1): 29-36.

GAMS I., 1991a. The origin of the term karst in the time of transition of Karst (Kras) from deforestation to forestation. Proc. of I.C.E.C.K.A., Quaderni del Dipartimento di Geografia dell'Università di Padova, 13: 1 - 8.

GAMS I., 1991b. Sistemi prilagoditve primorskega Dinarskega krasa na kmetijsko rabo tal (Systems of adapting the Littoral Dinaric Karst to agrarian land use). Geografski zbornik (Acta Geographica), XXXI (1991): 7-106.

GUSIC B., 1957. Covjek i kras (Man and karst). Krs Jugoslavije, 1, JAZU, Zagreb.

GUSIC B., 1971. Covjek i priroda u krasu skozi stoljeca (Man and nature on karst through centuries). JAZU, Zagreb.

HARDING K. A., FORD D. C., 1993. Impacts of Primary Deforestation upon Limestone slopes in the Northern Vancouver Island. British Columbia. Environmental Geology 21: 137143.

MAN'S IMPACT IN DINARIC KARST, Guide book, 1987. Ljubljana.

ROGLIC J., 1965. The delimitation and morphological types of the Dinaric Karst. Nase jame VII (1- 2): 12 - 20.

Savezno savetovanje o krsu (Federal conference on karst), 1957. t. I (275 p.), t. II (346 p.), t. III (230 p.), t. IV (159 p.), t. V (269 p.). Sumarsko drustvo, NR Hrvatske. Split.

Scientific Council of Vegetation Map of Yugoslavia. Prirodna potencialna vegetacija Jugoslavije (Natural potential vegetation of Yugoslavia). Commentary to the map $1: 1,000$. Ljubljana.

Statisticki godisnjak FNRJ 1962. Beograd.

Statisticki godisnjak SFRJ 1963. Beograd.

Statisticki godisnjak Jugoslavije 1990. Beograd.

Statisticki godisnjak SR Hrvatske 1988. Zagreb.

Statisticki ljetopis (Statistical Yearbook) 1997. Zagreb.

XIAOPING C., 1998. The analysis research on soil erosion characters in karst mountains area environment Xichon of Yunnan. South China Karst I, Ljubljana: 127-133. 